\title{
Paid Consulting in Ontario Colleges of Applied Arts and Technology $\Delta$
}

\section{STEPHEN BELL* \& GLEN A. JONES ${ }^{\dagger}$}

\begin{abstract}
A survey of faculty participation in paid consulting arrangements in Ontario Colleges of Applied Arts and Technology reveals that $34 \%$ were involved in at least one project during a specified one-year period. There was significant variation in participation by division of academic appointment and by gender. The authors suggest that further research should be undertaken concerning the nature and role of paid consulting in community colleges. $A$ number of basic questions are raised in an attempt to induce further study on this important topic.
\end{abstract}

\section{Résumé}

Cette étude porte sur le niveau de consultation rémunérée effectuée par les membres du corps professoral des Collèges des arts appliqués et de la technologie de l'Ontario. Elle révèle que $34 \%$ d'entre eux ont été impliqués dans au moins un projet au cours d'une même année; on note que cette participation variait de façon significative selon le genre et la position académiques en question. Les auteurs suggèrent que des études plus poussées soient entreprises quant à la nature et au rôle de la consultation rémunérée dans les collèges communautaires; ils soulèvent également des questions fondamentales voulant inciter à d'autres recherches sur ce sujet d'importance.

*Faculty of Arts, York University.

†Faculty of Education, Brock University.

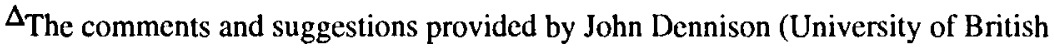
Columbia), Sue Elgie, and Michael Skolnik (Ontario Institute for Studies in Education) are gratefully acknowledged. 
Teaching has always been the central function of Canadian community colleges, in marked contrast to the university sector where faculty are expected to engage in some combination of teaching, research, and service activities (Dennison \& Gallagher, 1986). In Ontario Colleges of Applied Arts and Technology (CAATs), the emphasis on teaching and learning has formed the basis for workload formulas which govern faculty assignments, and it is the central focus of institutional mission statements. This is not to suggest that community college faculty are not involved in research or service activities, ${ }^{1}$ but rather that these activities are usually described in terms related to, or as a function of, the teaching mission. In the university sector, teaching, research, and service are usually described as complementary or inter-related faculty activities; but in the community college sector, research and service are viewed as professional development activities which contribute to teaching.

One faculty activity is paid consulting, an activity which, in the university sector, is legitimised as either research or service, but, in the community college sector, is legitimised in terms of the professional development of teachers. ${ }^{2}$ While the level and role of paid consulting in the university sector has been the subject of some study (Boyer \& Lewis, 1985), we know very little about paid consulting in the community colleges. This paper represents an attempt, by the authors, to induce research activity on this subject by providing some basic data and discussing a number of questions that might be addressed through further study and research. Thus, we will report data on paid consulting activities of Ontario CAAT faculty obtained from a larger survey on applied research (Bell, $1989,1992)$. How many community college faculty participate in paid consulting $^{3}$ arrangements? Does the level of consulting activity vary by teaching area, gender, and level of formal education? For whom do faculty consult; and how much time do they devote to such activities? The paper will conclude with a discussion of a number of major questions which relate to consulting activities in community colleges.

\section{Background}

The Ontario CAATs have always been functionally differentiated from the provincial university sector. Their original mandate, which has changed very little in their twenty-year history (Dennison \& Gallagher, 1986, pp. 95-100; Jones, 1991), was to develop skilled manpower for a highly industrialized province through a combination of federally and provincially supported programs. Articulation between the CAAT sector and the university sector has been quite limited, and the question of credit transferability is left to the discretion of the institutions (Skolnik \& Jones, forthcoming). 
The centrality of the teaching function in the CAAT system has left little room for attention to non-teaching-related activities. Labour disputes, which have had an important impact on the College environment, have often centred on workload, defined as instructional assignment (Skolnik, 1988). These workload agreements govern teaching and teaching-related functions.

Consulting, in the university sector, has generally been described as a service activity involving the application of knowledge (Boyer \& Lewis, 1985, p .3). Consulting may provide faculty with an opportunity to test whether concepts and theories hold up when applied (Aggarwall, 1981, p. 17; Redding, 1983, p. 19), to work and interact with non-academic colleagues, to receive "external confirmation of the quality and relevance of the faculty member's expertise" (Boyer \& Lewis, 1985, p. 10), and to supplement their income (Glauser \& Axeley, 1983; Payne \& Desman, 1987). Faculty consulting may also provide benefits to the institution by contributing to the institution's reputation, demonstrating service to the external environment (Golomb, 1979; Patton, 1980; Aggarwall, 1981), and, by supplementing individual salaries, allowing the institution to retain (Golomb, 1979) or acquire qualified personnel (Tuckman, 1984). Further benefits may accrue to society since consulting often involves a sharing of academic expertise with the private sector (Tuckman, 1984), and it promotes the transfer of ideas and technological development (Bok, 1982; Howsam, 1985).

The problems that are associated with consulting include the possible neglect of students, concerns over the earning of outside income on university time (Patton \& Marver, 1979; Payne \& Desman, 1987), and the potential for illegitimate use of institutional resources such as computers, telephones, and office supplies (Yuker, 1984; Payne \& Desman, 1987). Given these various viewpoints and the lack of a theory on which to base research on paid consulting (Boyer \& Lewis, 1985), it is not surprising that the topic of external service in the university sector "remains taboo" (Blackburn, 1978).

Given the centrality of the teaching mission in Canadian community colleges, it is generally argued that consulting is a form of individualised professional development, though the topic has received no attention in the higher education literature. It is assumed that consulting provides faculty with an opportunity for professional development, to apply the concepts and theories they teach in the classroom and to expand their knowledge of a particular subject area. But is this in fact the case? In a study of faculty development structures and activities in Ontario CAATs, Geis and Jones (1990) found that at least four colleges "encourage faculty to obtain short-term industry-based positions 
as a method of renewing field-based knowledge and experience" (p. 12), and at least one college had a policy requiring faculty to obtain this type of position once every three years.

While consulting activities in the college environment are often discussed in terms of their relationship to the teaching mission, they might also be viewed as a form of applied research, depending on the nature of the work that is being done. There are those who argue that the mission of the community college should be expanded and that community colleges should be openly involved in applied research (Dennison \& Gallagher, 1986; Borins \& Holloway, 1989), and that such activities are "related to the very essence of service that the college is providing to the industrial system" (Pitman, 1986, p. 9).

\section{Methodology and Limitations of the Data}

Nine out of 22 Ontario community colleges ${ }^{4}$ were selected by a systematic sample with probability proportionate to faculty size with random start. The sample was self-weighted as the questionnaire was distributed to 25 percent of fulltime postsecondary faculty. ${ }^{5}$ Faculty were chosen randomly from an alphabetical list provided by each institution in March of 1989. 394 responses out of a possible 865 were received, an overall response rate of 46 percent. Individual college response rates varied from 37 percent to 61 percent. Two of the nine selected colleges withdrew from the study. One did not agree with certain questions in the questionnaire, while the second was abnormally late in distributing the questionnaire. An analysis of the program structures of the withdrawn colleges indicated that they were similar in size and shared similar regional characteristics with other colleges included in the sample.

The sample was 57.5 percent male and 42.5 percent female. The approximate mean age was 46.5 years, with 10 percent between the ages of 25 and 34 , 52 percent between the ages of 35 and 49 , and 37 percent between the ages of 50 and 64. Four percent of faculty had doctoral degrees, 34 percent had master's degrees, 14 percent professional degrees, 26 percent either three or four year bachelor's degrees, 12 percent some university training (did not receive a bachelor's degree) and 11 percent community college training. Finally, the average number of years of teaching experience was 11.6 (12.8 years for men and 10 years for women).

In terms of the representativeness of this sample with community college faculty in Ontario, it should be noted that these data are consistent with 1987-88 Statistics Canada (unpublished) data in terms of gender and teaching experience. For example, according to the Statistics Canada data, 56 percent of 
faculty were male, 44 percent female. The average number of years of teaching experience was 12.1 (13.2 for men and 10.7 for women). The study sample appears to be over-represented in terms of formal academic qualifications. The Statistics Canada data indicate that three percent had doctoral degrees, 18 percent had master's degrees, 11 percent had professional degrees, and 37 percent had bachelor's degrees. Differences in formal academic qualifications can be attributed to the fact that available data only reflect the entering qualifications of faculty, are not systematically updated, and are therefore out of date. Thus, the evidence suggests that the sample is representative of community college faculty in Ontario.

Faculty were asked to indicate their college division or school, or, if they taught in more than one division or school, to indicate the division or school to which they were primarily responsible. Data were broken down into five division categories: applied arts, business, health sciences, technology, and other. The "other" category represents faculty who are not appointed or primarily responsible to one of the four major units, and it includes those appointed to institution-specific units such as natural resources or hospitality and tourism management. Nineteen percent of the sample taught in business, 26 percent in technology, 26 percent in applied arts, 18 percent in health sciences, and 11 percent in other programs.

As part of a section of the questionnaire dealing with applied research activities, faculty were asked to indicate whether or not they were engaged in paid consulting with an off-campus organization during a specified twelve month period and to specify the number of such arrangements and the number of hours of work by category of sponsor.

Finally, general comments from some faculty suggested a degree of reluctance in reporting involvement in consulting arrangements, suggesting that the study findings may be understated. For example, six respondents provided information on the number of consulting projects they worked on but did not indicate the number of consulting hours.

\section{Results}

Responses to the questionnaire revealed a moderate to heavy involvement of faculty in consulting, depending on divisional appointment (Table 1). Thirty-four percent of all respondents engaged in at least one such arrangement; 13 percent of respondents reported their participation in only one such arrangement; while slightly more than one in ten respondents indicated that they had engaged in more than three consulting projects. 
Activity by divisional appointment varied considerably: 47 percent of business faculty, 37 percent of technology faculty, 13 percent of health sciences faculty, 35 percent of applied arts faculty and 32 percent of other faculty engaged in consulting in the period defined. Business faculty seem particularly heavily involved in consulting, with approximately 18 percent engaged in more than three consulting projects.

There was also a considerable difference in participation by faculty gender. More than twice as many men (43\%) engaged in consulting activities than women $(20 \%)$ during the one year period.

Table 1

Involvement by Community College Faculty in Paid Consulting by Division Appoinment \& Gender in Percentages

Division of
Appointment

Business

Technology

Health Sciences

Applied Arts

Other

All

\section{Gender}

Male

Female

All

To determine whether there were any statistically significant differences and statistical interaction between divisional appointment (teaching area), gender, and level of education, a log linear analysis was undertaken. This method was chosen as the most appropriate because of the either/or characteristic; i.e., either you consulted or you did not. For the purposes of analysis, the "divisions" were ordered so that the division with the most consulting activity (Business) would be the one contrasted with each of the others. The variable "level of education" was broken down into two categories - those who possessed a Master's or higher degree and those who did not. This categorisation was seen as reasonable on the assumption that the more formal one's qualifications are, the more one may be asked to consult. 
The model illustrated (Table 2) is a saturated model containing all of the main effects and interactions, but it does not include the variable "level of education" as that was not found to be statistically significant and was dropped from the model. The results of the contrasts indicate that there are no statistically significant effects of division, although the contrast between the Business and Health Science divisions approaches significance $(\mathrm{p}<.06)$.

The data illustrate a strong effect of gender $(p<.01)$, and an interaction between gender of the Business and Technology divisions ( $\mathrm{p}<.02)$. The apparent differences by division would seem to reflect the primary influences of gender.

Respondents also indicated the number of paid-consulting projects and the number of hours devoted to such projects by category of sponsor ${ }^{6}$ (Table 3 ). The majority of all projects $(55 \%)$ and consulting hours $(59 \%)$ were sponsored by business or industry, a fact which provides some support to those who argue that consulting is a form of knowledge transfer to the private sector. Approximately 24 percent of all projects, and 22 percent of all consulting hours, were sponsored by some level of government or government agency (local, provincial, or federal). A relatively small number of consulting projects were sponsored by foundations and foreign governments or agencies. On average, faculty spent 34 hours, or less than one work week, on each consulting project.

Table 2

Main Effects and Interaction Effects of Division of Appointment and Gender Saturated Model

\begin{tabular}{llcl}
\hline Effect & Parameter & Chi-Square & Prob< \\
\hline Division & & 6.29 & n.s. \\
& Div (Business*Technology) & 2.25 & n.s. \\
& Div (Business*Health Sciences) & 3.60 & .06 \\
& Div (Business*Applied Arts) & 0.02 & n.s. \\
& Div (Business*Other) & 0.22 & n.s. \\
& & 7.41 & .01 \\
Gender & & 5.59 & .02 \\
& Div*Gen (Business*Technology) & n.s. \\
& Div*Gen (Business*Health Sciences) & 0.17 & n.s. \\
& Div*Gen (Business*Applied Arts) & 0.02 & n.s. \\
& Div*Gen (Business*Other) & 0.39 & \\
\hline
\end{tabular}


Table 3

Consulting Projects and Project Hours by Category of Sponsor

\begin{tabular}{|c|c|c|c|c|c|c|c|}
\hline Category of Sponsor & $\mathrm{N}$ & $\begin{array}{c}\text { \# of } \\
\text { Projects }\end{array}$ & $\begin{array}{l}\% \text { of all } \\
\text { Projects }\end{array}$ & $\begin{array}{l}\text { Total } \\
\text { Hours }\end{array}$ & $\begin{array}{c}\% \text { of all } \\
\text { Hours }\end{array}$ & $\begin{array}{l}\text { Average } \\
\text { Number of } \\
\text { Hours per } \\
\text { Member }\end{array}$ & $\begin{array}{c}\text { Average } \\
\text { Number of } \\
\text { Hours per } \\
\text { Project }\end{array}$ \\
\hline Business or Industry & 79 & 229 & 54.9 & 8457 & 59.2 & 107 & 37 \\
\hline Federal Government/Agency & 16 & 46 & 11.0 & 1276 & 8.9 & 80 & 28 \\
\hline Provincial Government/Agency & 20 & 33 & 7.9 & 1148 & 10.1 & 72 & 44 \\
\hline College or University & 18 & 32 & 7.7 & 842 & 5.9 & 47 & 26 \\
\hline Other & 10 & 27 & 6.5 & 936 & 6.6 & 94 & 35 \\
\hline Local Government/Agency & 12 & 20 & 4.8 & 485 & 3.4 & 40 & 24 \\
\hline Elementary/Secondary School & 8 & 13 & 3.1 & 295 & 2.1 & 37 & 23 \\
\hline Foreign Government/Agency & 3 & 11 & 2.6 & 445 & 3.1 & 148 & 40 \\
\hline Foundation & 5 & 6 & 1.4 & 98 & 0.7 & 20 & 16 \\
\hline TOTAL & 171 & 417 & 100.0 & 14282 & 100.0 & 84 & 34 \\
\hline
\end{tabular}


They spent an average of 84 hours, or slightly more than two work weeks, on consulting during the one year period. ${ }^{7}$

\section{Discussion}

As illustrated previously, responses to the questionnaire revealed a moderate to high level of participation in consulting activity (34\% of all faculty). This figure is comparable to studies which suggest that approximately 37 percent of university faculty engage in consulting (Ladd \& Lipset, 1975; Marver \& Patton, 1976; Patton \& Marver, 1979). Boyer \& Lewis (1985, p. 18) note that prior studies present somewhat inconsistent results which may be a function of different research methods and sampling techniques; but the data from studies of university faculty, which often have a service mandate, are surprisingly close to the CAAT faculty data, where such a mandate does not formally exist. ${ }^{8}$

Like other studies on consulting in universities and colleges, this study focused on participation of faculty, but it represents only a starting place in addressing the larger questions related to the level and role of consulting in the community college sector. In general terms, these larger questions might be termed the "what", "why", and "when" of consulting.

The "what" question relates to the central and still unanswered question of the types of activities faculty are engaged in when they are engaged in consulting arrangements. We not only need to know what these activities are, but we also need to know what the relationship is between these activities and the teaching role of community college faculty. What skills or knowledge-bases are utilised in consulting assignments? What do participating faculty bring back with them to the classroom? Is consulting beneficial or detrimental to teaching?

The "why" question relates to those factors which influence faculty behaviour so that they participate in consulting. Are those who engage in consulting motivated by intellectual excitement, by perceived benefits in terms of their teaching role, by financial gain, or by some other factor? Why are males more likely to participate in consulting arrangements compared to their female colleagues, especially when female faculty have higher formal academic qualifications ( $41 \%$ have master's degrees or higher compared to $37 \%$ for men), and are only slightly less experienced than their male colleagues? If one were to use the argument that consulting is a factor in keeping faculty current in their teaching areas and contributing to their professional development, then further data need to be collected to validate this hypothesis. We also need to learn more about how consulting is viewed by the sponsors. Why do they enter into consulting arrangements with community college faculty instead of university faculty or 
private consulting firms? Do consulting arrangements with community college faculty have an impact on the way sponsors view community colleges?

The "when" question refers to the need to identify when these activities are taking place. Do consulting arrangements decrease faculty leisure time, or are these activities replacing, or competing with, more traditional faculty development opportunities? Do these activities compete with time for preparation, evaluation and giving attention to students?

\section{Conclusion}

The data reported present a a first step in investigating the phenomenon of consulting activity among community college faculty. The data illustrate the extent of faculty consulting by teaching area and indicate statistically significant differences by gender. The categories of sponsorship and the overall amount of time devoted to consulting activities are also shown.

Attempts must be made to address the what, why, and when questions discussed above. Our informal discussions with community college administrators and faculty have suggested that there are two contrasting perceptions on the level of consulting. Some view consulting as a small-scale activity performed by only a few faculty. Others view it as so common as to suggest that it endangers the teaching function of the community college system. The data presented here suggest that the real level of consulting activity falls somewhere between the two anecdote-based extremes. With one-third of faculty engaged in some form of consulting activity, a figure that increases to one-half in the Business Division, it is difficult to argue that the activity is limited to only a few. However, with the average time commitment being approximately two work weeks a year, one cannot argue prima facie that consulting, generally speaking, jeopardises the level or quality of teaching in community colleges. What is clear is that consulting is a faculty activity that is worthy of further inquiry.

\section{Notes}

${ }^{1}$ It is clear that many community college faculty are involved in research activities. A number of recent studies have focused on this topic (Bell, 1989, 1992; Sorensen, 1988).

${ }^{2}$ For example, the final report of the Vision 2000 review of Ontario Colleges of Applied Arts and Technology "urges the colleges to work together to foster applied scholarship activities by college personnel as a way of contributing to the overall goal of teaching excellence. For many teachers in the system, the most effective way to stay current in their field and improve their teaching is by participating in a range of activities - 
from problem solving and the transfer or diffusion of information and technology to the development of new services and products" (Vision 2000, pp. 19-20).

3 The paper deals only with paid consulting activities of community college faculty. Unpaid consultations, which may be numerous, are not measured.

4 A 23 rd community college was opened after this study was completed.

5 There are approximately 8,800 full-time faculty and 110,000 full-time students in Ontario Colleges of Applied Arts and Technology.

6 The number of times that faculty members engaged in paid consulting activities does not necessarily equal the number of projects on which they worked.

7 It is extremely important to note that the questionnaire did not ask faculty specifically to indicate when they engaged in paid consulting activities. Since the questionnaire asked for information on consulting activities over a twelve month period, the data should not be misinterpreted to suggest that faculty are earning supplemental income during time periods when they should be involved in teaching or teaching-related functions. Consulting activities might well be performed during hours that are not governed by the individual's instructional assignment, but this issue obviously requires further study.

8 While there are general similaritics concerning participation, it is extremely difficult to compare the findings of this study with previous surveys of faculty consulting in universities, especially since community college faculty in Ontario are categorized by program division and not by discipline orientation.

\section{References}

Aggarwal, R. (1981). Faculty members as consultants: A policy perspective. Journal of the College and University Personnel Association, 32 (2), 17-20.

Bell, S. (1989). An exploratory survey on applied research and community college faculty in Ontario. Unpublished manuscript, Council of Regents of the Ontario Colleges of Applied Arts and Technology, Toronto.

Bell, S. (1992). Research activities and work satisfaction of community college faculty. The Review of Higher Education, 15 (3), 307-325.

Blackburn, R. T. (1978). Case studies of the academic profession. In Robert T. Blackburn (ed.). Studies on academics and modes of inquiry. Ann Arbor: University of Michigan, Centre for the Study of Higher Education.

Borins, S., \& Holloway, S. (1989) Meeting the competitive challenge: Enhancing applied research in Ontario's colleges. In Colleges and the changing economy: Background papers to Vision 2000, a review of the mandate of the Colleges of Applied Arts and Technology. Toronto: Council of Regents.

Bok, D. (1982). Beyond the ivory tower: Social responsibilities of the modern university. Cambridge, Mass.: Harvard University Press.

Boyer, C. M. \& Lewis, D. R. (1985). And on the seventh day: Faculty consulting and 
supplemental income. ASHE-ERIC Higher Education Report No. 3. Washington, D.C.: Association for the Study of Higher Education.

Dennison, J. D., \& Gallagher, P. (1986). Canada's community colleges: A critical analysis. Vancouver: University of British Columbia Press.

Geis, G. L., \& Jones, G. A. (1990). Faculty development structures and activities in Ontario's Colleges of Applied Arts and Technology. Paper presented at the Tenth Annual Conference on Teaching and Leaming in Higher Education, Montreal, June.

Glauser, M. J., \& Axeley, S. R. (1983). Consulting activities of university faculty members: Scope and depth of involvement. Group and Organizational Studies, 8 (3), 270-286.

Golomb, S. W. (1979). Faculty consulting: Should it be curtailed? National Forum: Phi Kappa Phi Journal, 69 (4), 34-37.

Howsam, R. B. (1985). Academic consulting in colleges and universities. Enclaves of intellectual and moral integrity. A Report of the Coordinating Board, Texas College and University System.

Jones, G. A. (1991). Modest modifications and structural stability: Higher education in Ontario. Higher Education, 21, 573-587.

Ladd, E.C., \& Lipset, S.M. (1975). The divided academy: Professors and politics. New York: McGraw-Hill.

Marver, J. D., \& Patton, C. V. (1976). The correlates of consultation: American academics in 'the real world.' Higher Education, 5 (3), 319-335.

Patton, C. V. (1980). Consulting by faculty members. Academe: Bulletin of the AAUP, $66(4), 181-185$.

Patton, C. V., \& Marver, J. D. (1979). Paid consulting by American academics. Educational Record, 60 (2), 175-184.

Payne, S. L., \& Desman, R. A. (1987). The academician as a consultant. In S. L. Payne and B. H. Charnov (eds), Ethical dilemmas for academic professionals. Springfield, Illinois: Charles C. Thomas.

Pitman, W. (1986). Report of the Advisor to the Minister of Colleges and Universities on the governance of the Colleges of Applied Arts and Technology. Toronto: Ministry of Colleges and Universities.

Redding, W. C. (1983). Resolved: That paid consulting is contrary to the best interests of academia - the negative. Association for Communication Administration Bulletin, 44, 17-20.

Skolnik, M. L. (1988). The evolution of relations between management and faculty in Ontario Colleges of Applied Arts and Technology. Canadian Journal of Higher Education, 18 (3), 83-112.

Skolnik, M. L., \& Jones, G. A. (Forthcoming). Arrangements for coordination between university and colleges sectors in Canadian provinces. Canadian Journal of Higher Education.

Sorensen, N. (1988). Canadian community colleges and institute-based research in the 
social sciences and humanities. Toronto: Association of Canadian Community Colleges.

Tuckman, H. P. (1984) [Book review of Dollars and scholars: An inquiry into the impact of faculty income upon the function and future of the academy, edited by Robert H. Linnell.] Journal of Higher Education, 55 (3), 430-432.

Vision 2000 (1990). Vision 2000: Quality and opportunity - A summary. Toronto: Ontario Ministry of Colleges and Universities.

Yuker, H. E. (1984). Faculty workload: Research, theory, and interpretation. ASHEERIC Higher Education Report No. 10. Washington, D.C.: Association for the Study of Higher Education. 